\title{
A Study on Variation of Thermal Characteristics of Insulation Materials for Buildings According to Actual Long-Term Annual Aging Variation
}

\author{
Hyun-Jung Choi ${ }^{1}$ • Jae-Sik Kang ${ }^{1}$. \\ Jung-Ho Huh ${ }^{2}$
}

Received: 8 May 2017 / Accepted: 17 October 2017 / Published online: 20 November 2017

(C) The Author(s) 2017. This article is an open access publication

\begin{abstract}
Insulation materials used for buildings are broadly classified as organic insulation materials or inorganic insulation materials. Foam gas is used for producing organic insulation materials. The thermal conductivity of foam gas is generally lower than that of air. As a result, foam gas is discharged over time and replaced by outside air that has relatively less thermal resistance. The gas composition ratio in air bubbles inside the insulation materials changes rapidly, causing the performance degradation of insulation materials. Such performance degradation can be classified into different stages. Stage 1 appears to have a duration of 5 years, and Stage 2 takes a period of over 10 years. In this study, two insulation materials that are most frequently used in South Korea were analyzed, focusing on the changes thermal resistance for the period of over 5000 days. The measurement result indicated that the thermal resistance of expanded polystyrene fell below the KS performance standards after about 80-150 days from its production date. After about 5000 days, its thermal resistance decreased by $25.7 \%$ to $42.7 \%$ in comparison with the initial thermal resistance. In the case of rigid polyurethane, a pattern of rapid performance degradation appeared about 100 days post-production, and the thermal resistance fell below the KS performance standards after about 1000 days. The thermal resistance decreased by $22.5 \%$ to $27.4 \%$ in comparison with the initial thermal resistance after about 5000 days.
\end{abstract}

Special Issue: Advances in Thermophysical Properties.

$\triangle \quad$ Jae-Sik Kang

jskang@kict.re.kr

1 Building and Urban Research Institute, Korea Institute of Civil Engineering and Building Technology, (daehwa-Dong)283, Goyangdae-Ro, Ilsanseo-Gu, Goyang-Si, Gyeonggi-Do 10223, Korea

2 Department of Architectural Engineering, University of Seoul, Seoulsiripdaero 163, Dongdaemun-Gu, Seoul 02504, Korea 
Keywords Actual long-term · Aging variation - Insulation materials - Thermal resistance

\section{Introduction}

The insulation materials used for a building directly affect its cooling and heating load, therefore significantly influencing energy bills throughout the building's lifecycle. The Korean government has been strengthening the relevant systems or policies in order to improve energy efficiency of buildings, e.g., continuous improvement of energy-efficient building design standards used for new buildings, and making efforts to operate the improvement and management measures for the insulation performance of existing buildings [1]. Insulation is a fundamental method to reduce building energy consumption, as it directly affects the cooling/heating load and energy consumption of a building. The insulation performance of building envelope is largely determined by the thermal properties of building insulating materials. Those thermal properties include the density and thermal conductivity. Existing insulation materials are often replaced through renovation once a building has reached its life span or has been in use for a long period of time after its initial construction. In general, it is expected that the life span of a building is over 50 years, and the renovation of building skin and insulation material is carried out 20-25 years after the initial construction of the building. Therefore, the objective of this study is to investigate the thermal properties of building insulation materials according to long-term aging variation. The study presents the result of a longitudinal experiment on the thermal conductivity of insulation materials. Insulation materials' performance data obtained throughout the study can be used as a basis of improving the competitiveness of insulation products in the market in the future. Thermal properties of different insulation materials due to longterm aging variation will be utilized to suggest the revision of the relevant standards and specifications of building insulation materials.

\section{Aging Characteristics of Plastic Insulation Material}

A blowing agent is used in plastic insulating material to create closed cells inside the insulation material and to improve the insulation performance. The thermal conductivity of a blowing agent is generally lower than that of air. The thermal performance of plastic insulation material is deteriorated over time because nitrogen and oxygen in the air permeate into air bubbles at high speed, causing the primary thermal drift. Additionally, internal gas, which has relatively large thermal resistance, is released to the outside at a slower pace in comparison with air penetration. Figure 1 shows the mechanism of how the insulation performance is deteriorated due to the replacement of foam gas and air [2].

(1) Change in the 1st stage (primary stage): As the change according to rapid change of gas ratio in air bubbles inside the insulation material due to air penetration from the outside occurs, thermal drift occurs. (Generally, this change comes to an end within 5 years.) 

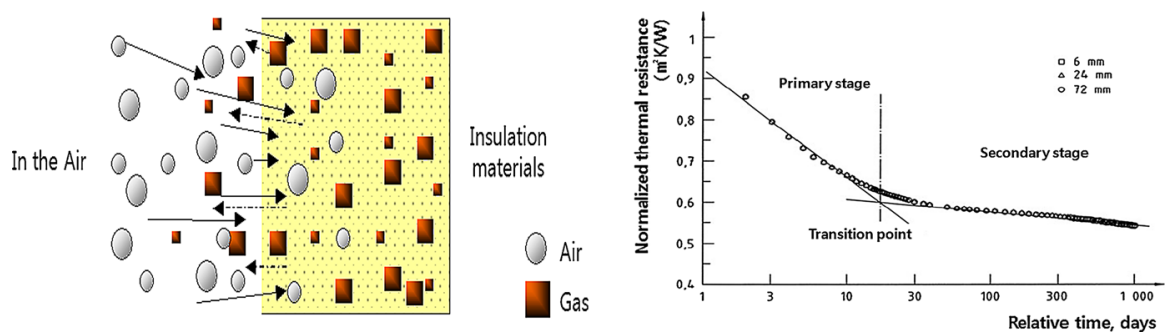

Fig. 1 Aging mechanism and aging characteristic of closed-cell plastics by normalize process

(2) Change in the 2nd stage (secondary stage): Deterioration of thermal performance occurs due to slow release of gas penetrated into internal air bubbles to the outside, while air penetration from the outside is stopped. (This occurs for over 10 years and in some cases, over 100 years.)

\section{Test Method}

\subsection{Specimen and Measurement Conditions}

The specimens used in the experiment were Special Class and Class 1 expanded polystyrene foam, and $40 \mathrm{~K}$ and $50 \mathrm{~K}$ rigid polyurethane foam (specifications shown in Table 1) that were used as the insulation materials for buildings. These insulation materials were collected within 3 days from the production date and installed on the actual wall of the sample building as shown in Fig. 2. The experimental conditions include two cases: (1) installation of the specimen at the back of the class surface (1st floor) so that it is directly affected by the external condition, and (2) installation of the specimen inside the wall (2nd floor). The size of each insulation material specimen was $300(\mathrm{~W}) \times 300(\mathrm{H}) \times 50(\mathrm{D}) \mathrm{mm}$ and each specimen consisted of independent cells as shown in Fig. 2. Also, Fig. 2 shows the external view of the experiment setup and the cross section of the area where each insulation material specimen is installed.

The specimens for measuring the thermal conductivity were stored and managed in the constant temperature and humidity room prior to the experiment (temperature $20 \pm 5^{\circ} \mathrm{C}$, and RH $40 \pm 5 \%$ ), in accordance with KS A 0006 (standard atmospheric conditions for testing) and KS M 3808 (cellular polystyrene(PS) for thermal insulation).

\subsection{Measurement Equipment}

Netzsch's Heat Flow Meters HFM 436 Lambda Series was used for thermal conductivity measurements in this study. Experiments were carried out in accordance with the measurement method specified in ASTM C 518 (standard test method for steadystate thermal transmission properties by means of the heat flow meter apparatus) and ISO 8301 (thermal insulation-determination of steady-state thermal resistance and 
Table 1 Thermal conductivity of expanded polystyrene and rigid polyurethane $[4,5]$

\begin{tabular}{|c|c|c|}
\hline Materials & $\begin{array}{l}\text { Thermal conductivity } \\
{\left[\mathrm{W} \cdot \mathrm{m}^{-1} \cdot \mathrm{K}\left(\mathrm{kcal} \cdot \mathrm{m}^{-1} \cdot \mathrm{h} \cdot{ }^{\circ} \mathrm{C}\right)\right]}\end{array}$ & Density $\left(\mathrm{g} \cdot \mathrm{cm}^{-3}\right)$ \\
\hline \multicolumn{3}{|c|}{ Expanded polystyrene } \\
\hline \multicolumn{3}{|c|}{ Expandable polystyrene (EPS) } \\
\hline $1 \mathrm{st}$ & $0.036(0.031)$ & $\geq 30$ \\
\hline 2 nd & $0.037(0.032)$ & $\geq 25$ \\
\hline 3 rd & $0.040(0.034)$ & $\geq 20$ \\
\hline 4 th & $0.043(0.037)$ & $\geq 15$ \\
\hline \multicolumn{3}{|c|}{ Extruded polystyrene (XPS) } \\
\hline Special & $0.027(0.023)$ & - \\
\hline $1 \mathrm{st}$ & $0.028(0.024)$ & - \\
\hline 2nd & $0.029(0.025)$ & - \\
\hline $3 r d$ & $0.031(0.027)$ & - \\
\hline \multicolumn{3}{|c|}{ Rigid polyurethane } \\
\hline \multicolumn{3}{|c|}{1 class } \\
\hline $1 \mathrm{st}$ & $0.024(0.021)$ & $\geq 45$ \\
\hline 2 nd & $0.024(0.021)$ & $\geq 35$ \\
\hline $3 \mathrm{rd}$ & $0.026(0.022)$ & $\geq 25$ \\
\hline \multicolumn{3}{|l|}{2 class } \\
\hline $1 \mathrm{st}$ & $0.023(0.020)$ & $\geq 45$ \\
\hline 2nd & $0.023(0.020)$ & $\geq 35$ \\
\hline $3 \mathrm{rd}$ & $0.028(0.024)$ & $\geq 25$ \\
\hline
\end{tabular}

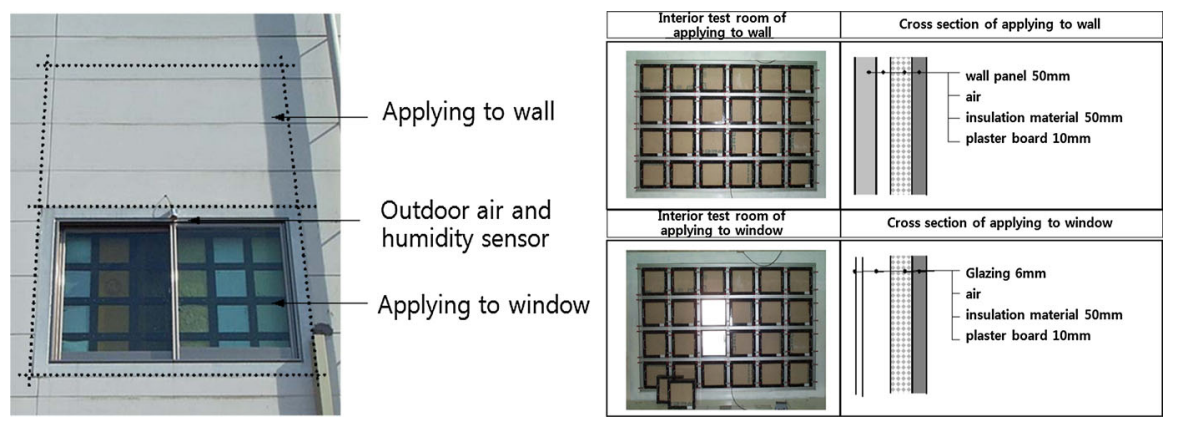

Fig. 2 Exterior/interior of test room and cross section of wall

related properties). The specification of the equipment and the diagram of measurement method are described in Table 2 and Fig. 3 respectively.

The thermal conductivity measurement method measures heat flow by inserting a specimen between an upper high-temperature panel and a lower low-temperature panel having a heat flow sensor by a plate heat flow method. At this time, the average temperature was set to $20^{\circ} \mathrm{C}[3,6]$. 
Table 2 Outline of measurement equipment

\begin{tabular}{ll}
\hline Measuring range & $0.015-0.43 \mathrm{~W} \cdot \mathrm{m}^{-1} \cdot \mathrm{K}$ \\
Size of specimens & $300 \times 300 \mathrm{~mm}, \mathrm{~d}=5-100 \mathrm{~mm}$ \\
Reproducibility & $\pm 1 \%$ \\
\hline
\end{tabular}

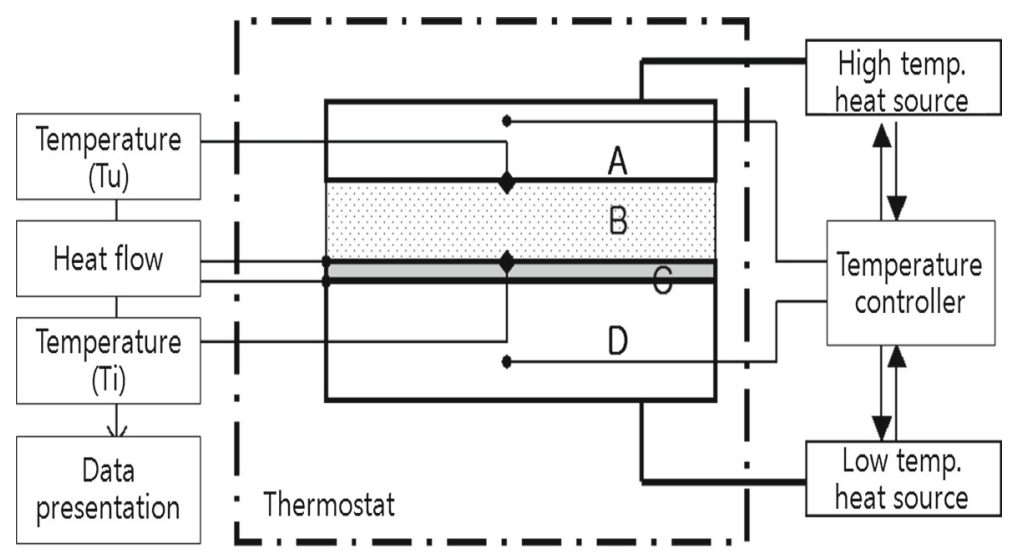

A: High temp. plate $\quad B$ : Specimens C: Heat flow meter $\quad$ D: Low temp. plate

Fig. 3 Outline of thermal conductivity test method by heat flow meter

\section{Test Result}

\subsection{Expanded Polystyrene Type 1}

The initial thermal resistance of the Special Class expanded polystyrene insulation material type 1 specimen was $2.485 \mathrm{~m}^{2} \cdot \mathrm{K} \cdot \mathrm{W}^{-1}$, and it decreased gradually over time. It decreased to $1.965 \mathrm{~m}^{2} \cdot \mathrm{K} \cdot \mathrm{W}^{-1}$ after about 100 days, $1.493 \mathrm{~m}^{2} \cdot \mathrm{K} \cdot \mathrm{W}^{-1}$ after about 1000 days and $1.424 \mathrm{~m}^{2} \cdot \mathrm{K} \cdot \mathrm{W}^{-1}$ after about 5000 days. Also, the thermal drift below the performance standards specified in KS standards was shown after about 150 days. The initial thermal resistance of the Class 1 expanded polystyrene insulation material type 1 specimen was $2.221 \mathrm{~m}^{2} \cdot \mathrm{K} \cdot \mathrm{W}^{-1}$, and it decreased to $1.687 \mathrm{~m}^{2} \cdot \mathrm{K} \cdot \mathrm{W}^{-1}$ after about 100 days, showing thermal drift. Also, it decreased to $1.368 \mathrm{~m}^{2} \cdot \mathrm{K} \cdot \mathrm{W}^{-1}$ after about 1000 days and $1.338 \mathrm{~m}^{2} \cdot \mathrm{K} \cdot \mathrm{W}^{-1}$ after about 5000 days, showing continuous thermal drift. The thermal drift below KS performance standards occurred after about 60 days, earlier than that of the Special Class expanded polystyrene insulation material type 1 . The initial insulation performance of expanded polystyrene insulation material type 1 decreased by about $38.5 \%$ to $40.1 \%$ after 1000 days. It maintained similar thermal resistance after about 5000 days, indicating that the specimens entered into the steady state after 1000 days. Before the experiment, it was anticipated that the thermal drift of the specimen installed on the glass window would be higher than the that of the specimen installed on the wall, due to the direct influence from the external conditions. However, the result of the experiment shows that there was no significant 


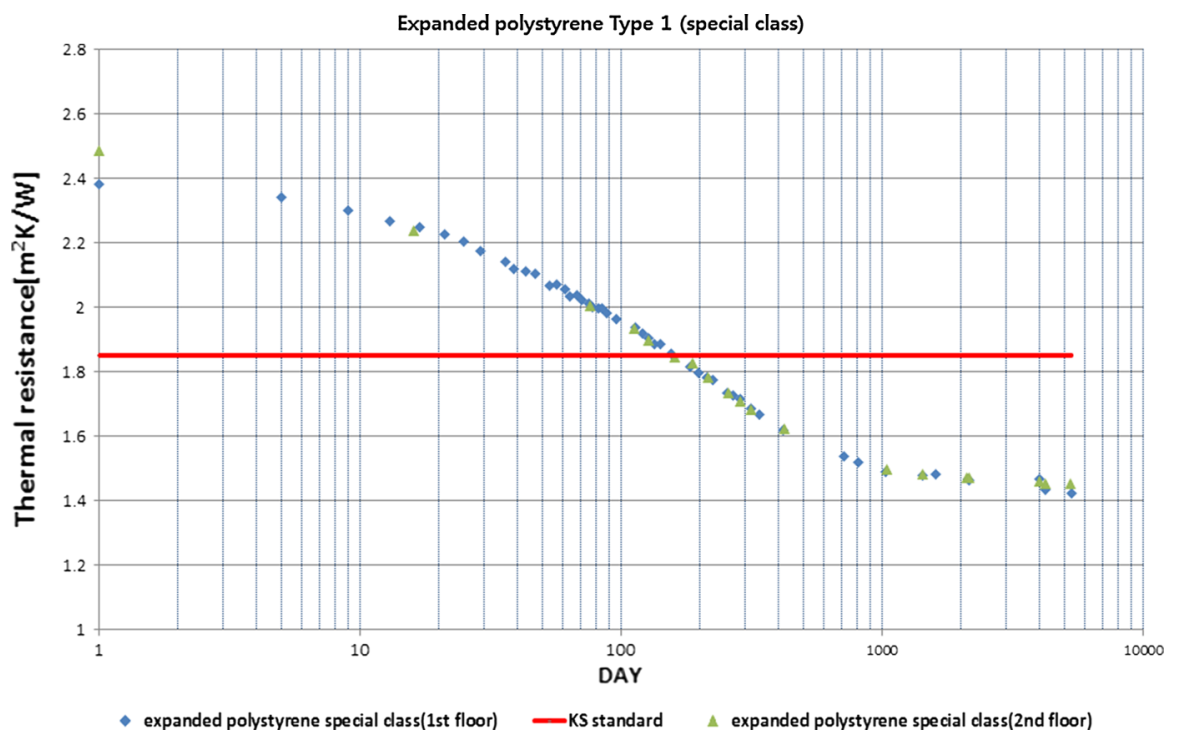

Fig. 4 Thermal resistance of expanded polystyrene type 1 (Special Class)

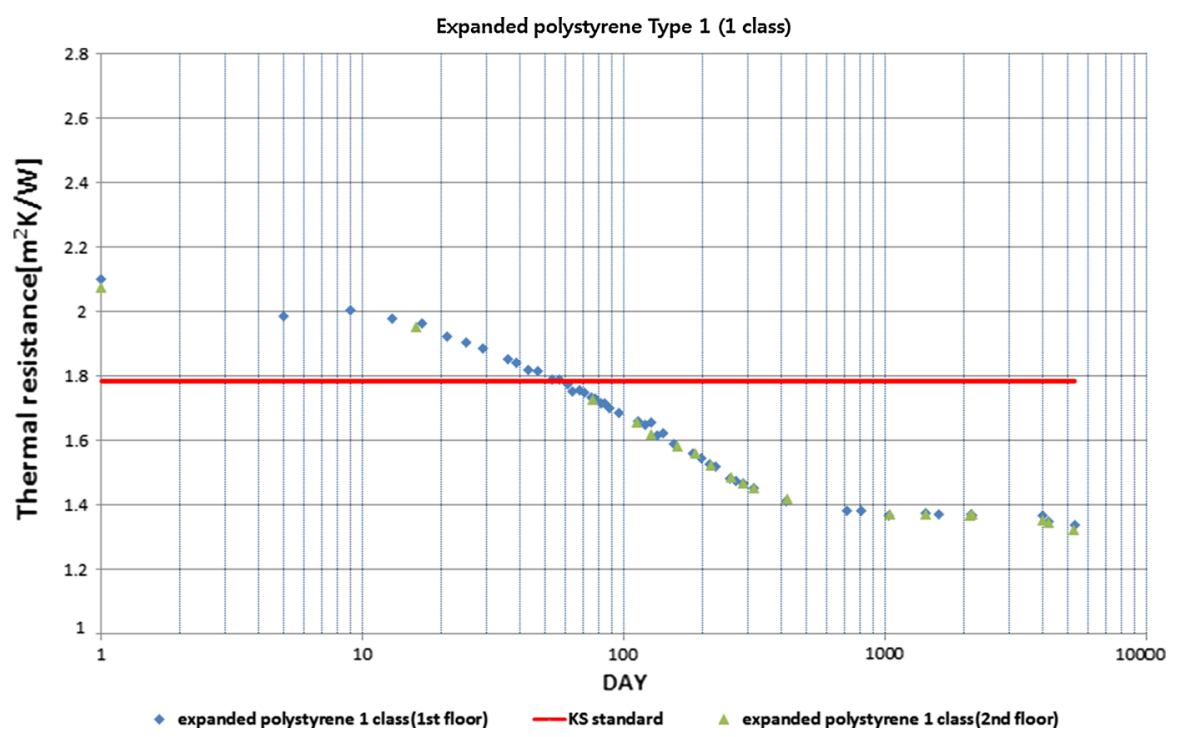

Fig. 5 Thermal resistance of expanded polystyrene type 1 (Class 1)

difference in the thermal drift between the two specimens. Figures 4 and 5 show the change in thermal resistance for the Special Class and Class 1 expanded polystyrene insulation material type 1 . 


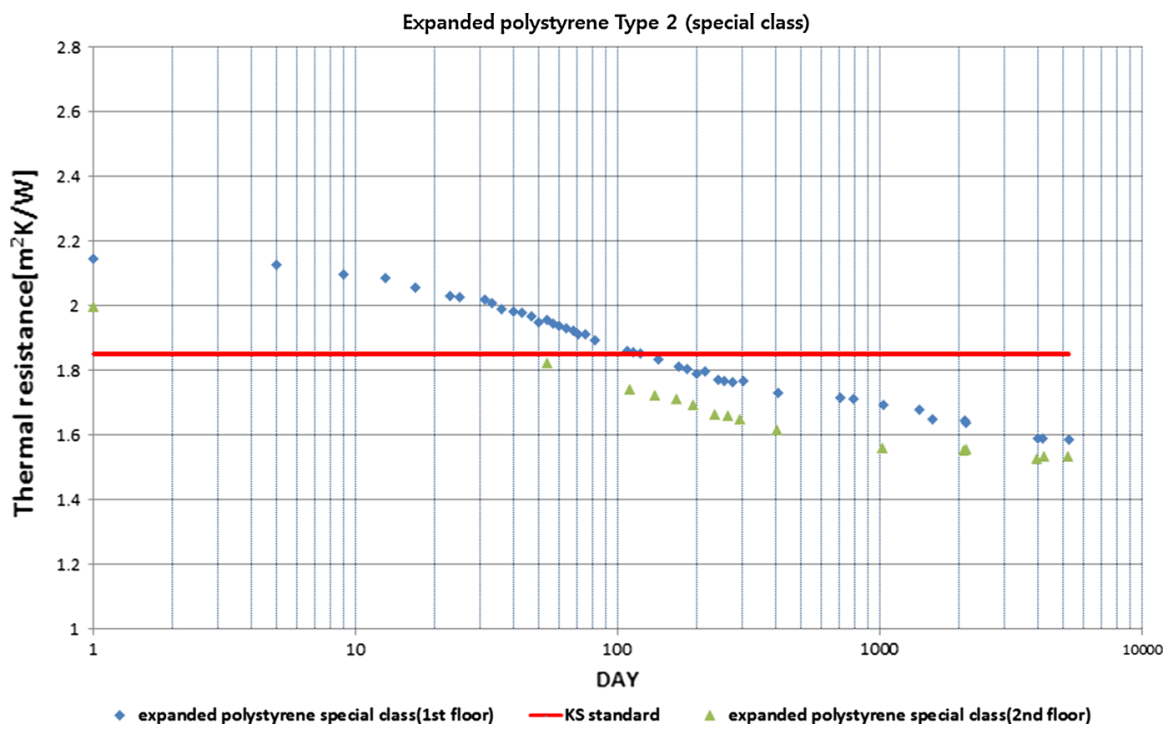

Fig. 6 Thermal resistance of expanded polystyrene type 2 (Special Class)

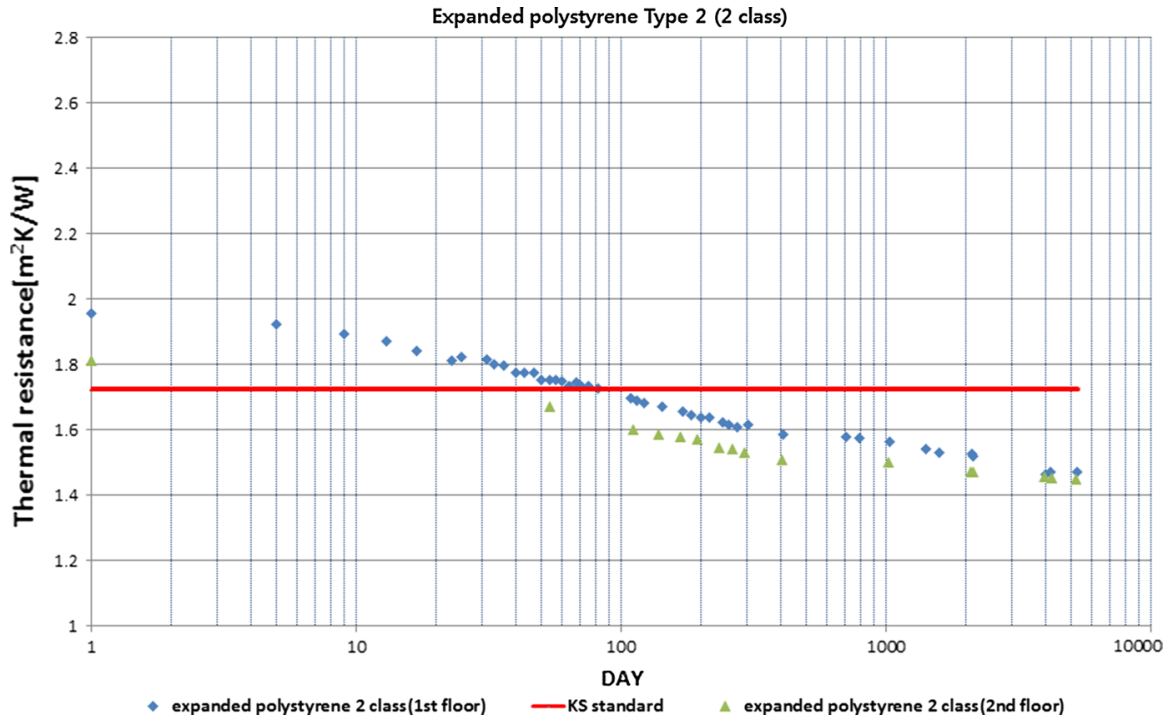

Fig. 7 Thermal resistance of expanded polystyrene type 2 (Class 2)

\subsection{Expanded Polystyrene Type 2}

The initial thermal resistance of the Special Class expanded polystyrene insulation material type 2 specimen was $2.157 \mathrm{~m}^{2} \cdot \mathrm{K} \cdot \mathrm{W}^{-1}$, and it decreased to $1.860 \mathrm{~m}^{2} \cdot \mathrm{K}$. $\mathrm{W}^{-1}$ after 100 days, showing thermal drift. It decreased to $1.694 \mathrm{~m}^{2} \cdot \mathrm{K} \cdot \mathrm{W}^{-1}$ after about 1000 days and $1.575 \mathrm{~m}^{2} \cdot \mathrm{K} \cdot \mathrm{W}^{-1}$ after about 5000 days. Also, the thermal 


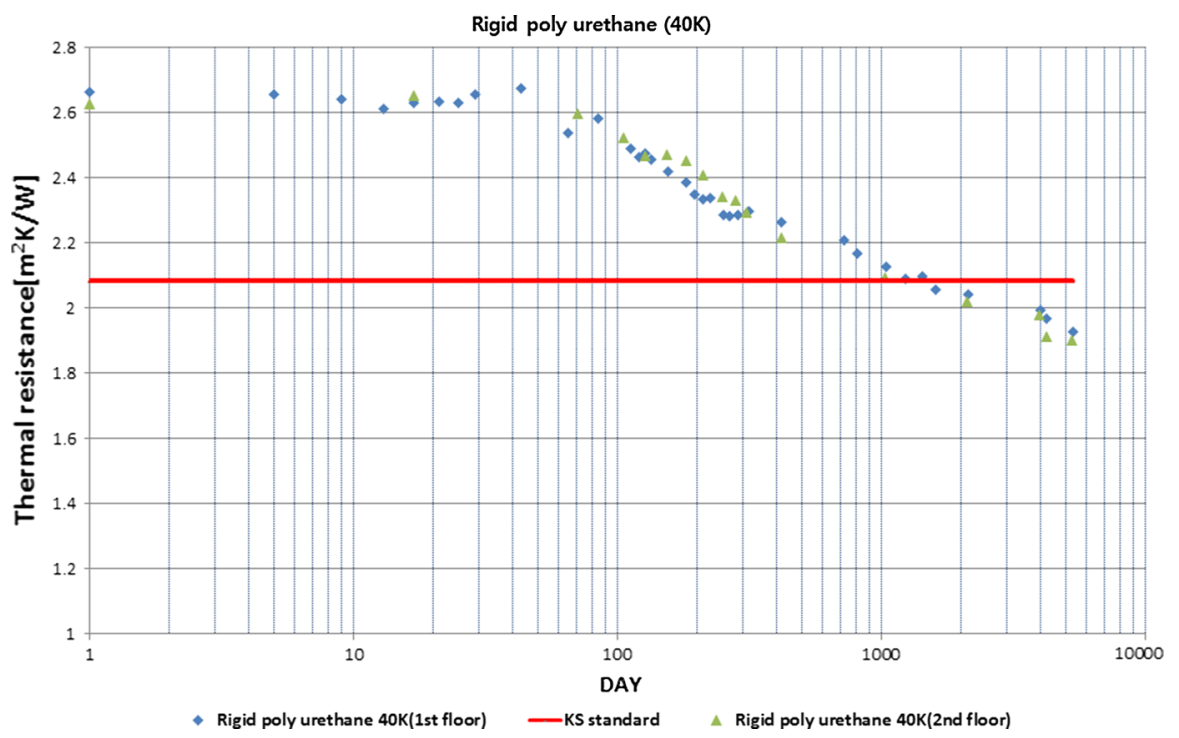

Fig. 8 Thermal resistance of rigid polyurethane (40 K)

performance falling below KS performance standards was shown after about 80 days from its production date.

The initial thermal resistance of the Class 2 expanded polystyrene insulation material type 2 specimen was $1.984 \mathrm{~m}^{2} \cdot \mathrm{K} \cdot \mathrm{W}^{-1}$, and it decreased to $1.698 \mathrm{~m}^{2} \cdot \mathrm{K} \cdot \mathrm{W}^{-1}$ after about 100 days, showing thermal drift. After that, it decreased to $1.566 \mathrm{~m}^{2} \cdot \mathrm{K} \cdot \mathrm{W}^{-1}$ after about 1000 days and $1.472 \mathrm{~m}^{2} \cdot \mathrm{K} \cdot \mathrm{W}^{-1}$ after about 5000 days, showing the pattern of continuous thermal drift. Also, the thermal performance falling below KS performance standards was shown after about 50 days from its production date.

The initial insulation performance of expanded polystyrene insulation material type 2 decreased by $21.0 \%$ to $21.4 \%$ after 1000 days. It also decreased by $25.9 \%$ to $27.0 \%$ after about 5000 days, indicating that the thermal drift was still in progress. Comparing the pattern of thermal drift between the specimens installed on the glass window exposed to solar radiation and the other installed on the wall, while the difference between the initials value was maintained for a certain period of time the gap between them became smaller after about 4000 days (Figs. 6, 7).

\subsection{Rigid Polyurethane}

The initial thermal resistance of rigid polyurethane insulation material $40 \mathrm{~K}$ specimen was $2.656 \mathrm{~m}^{2} \cdot \mathrm{K} \cdot \mathrm{W}^{-1}$, and it decreased to $2.486 \mathrm{~m}^{2} \cdot \mathrm{K} \cdot \mathrm{W}^{-1}$ after about 100 days, showing the pattern of thermal drift. It is about $6.3 \%$ rate of change, showing lower thermal drift in comparison with the expanded polystyrene insulation material. However, the pattern of rapid thermal drift was shown after 100 days, and the thermal resistance decreased to $2.128 \mathrm{~m}^{2} \cdot \mathrm{K} \cdot \mathrm{W}^{-1}$ after about 1000 days, falling below $\mathrm{KS}$ 


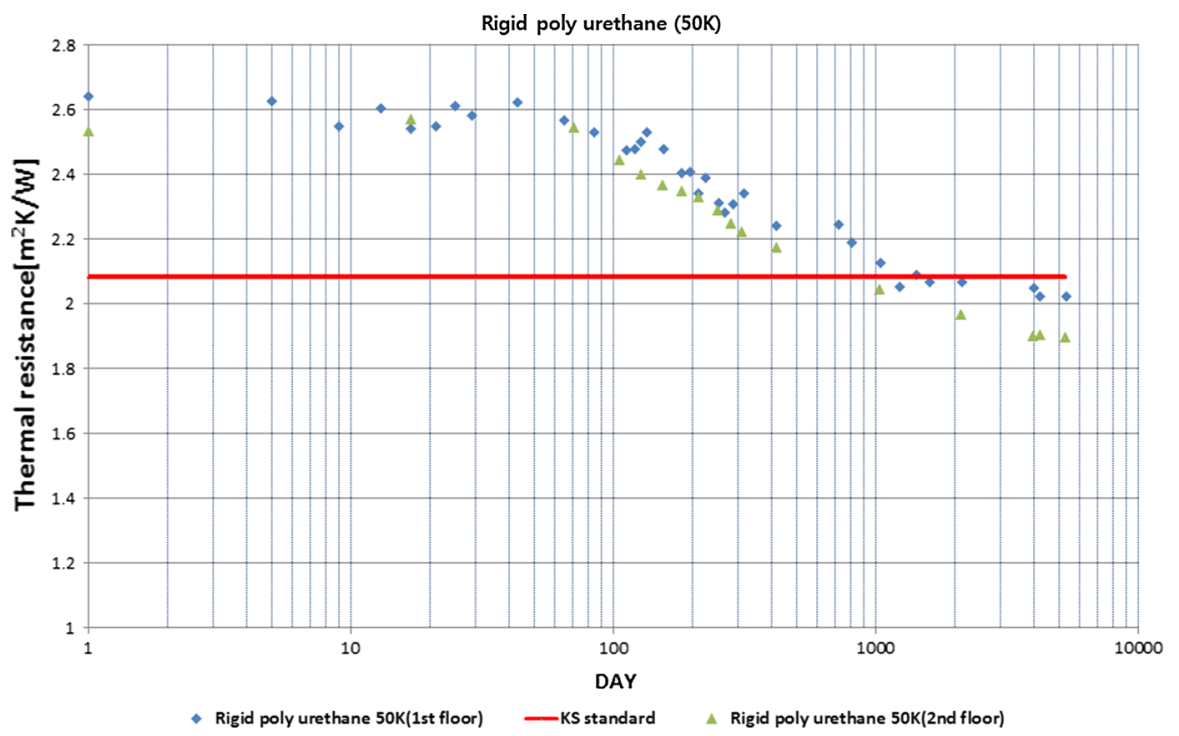

Fig. 9 Thermal resistance of rigid polyurethane $(50 \mathrm{~K})$

performance standards. It decreased to $1.929 \mathrm{~m}^{2} \cdot \mathrm{K} \cdot \mathrm{W}^{-1}$ after 5000 days, showing thermal drift, and it is considered that thermal drift is still in progress.

The initial thermal resistance of rigid polyurethane foam insulation material $50 \mathrm{~K}$ specimen was $2.613 \mathrm{~m}^{2} \cdot \mathrm{K} \cdot \mathrm{W}^{-1}$, and it decreased to $2.476 \mathrm{~m}^{2} \cdot \mathrm{K} \cdot \mathrm{W}^{-1}$ after about 100 days, showing the thermal drift. It registered about $5.2 \%$ rate of change, showing a small performance reduction ratio similar to that of the $40 \mathrm{~K}$ specimen. Then it decreased to $2.128 \mathrm{~m}^{2} \cdot \mathrm{K} \cdot \mathrm{W}^{-1}$ after about 1000 days, and the thermal performance falling below KS performance standards was shown after about 1200 days. This specimen did not show significant variations of its properties despite the exposure to solar radiation (Figs. 8, 9).

\section{Conclusion}

The aim of this study was to understand the patterns of change of thermal properties of different insulation materials. The study presented the result of the longitudinal experiment on the thermal conductivity of typically Korean building insulation materials. The specimens used in the experiment were expanded polystyrene and rigid polyurethane insulation materials. Long-term aging variation was measured for insulation materials that were influenced by outside air either directly or indirectly. The results of the analysis are summarized as follows (Table 3).

(1) The initial thermal resistance of Special Class and Class 1 expanded polystyrene insulation material type 1 within 3 days from its production date met KS performance standards. However, the pattern of continuous thermal drift was observed, and the thermal resistance falling below KS performance standards was shown after about 50-150 days. After about 1000 days, the specimens entered into the 


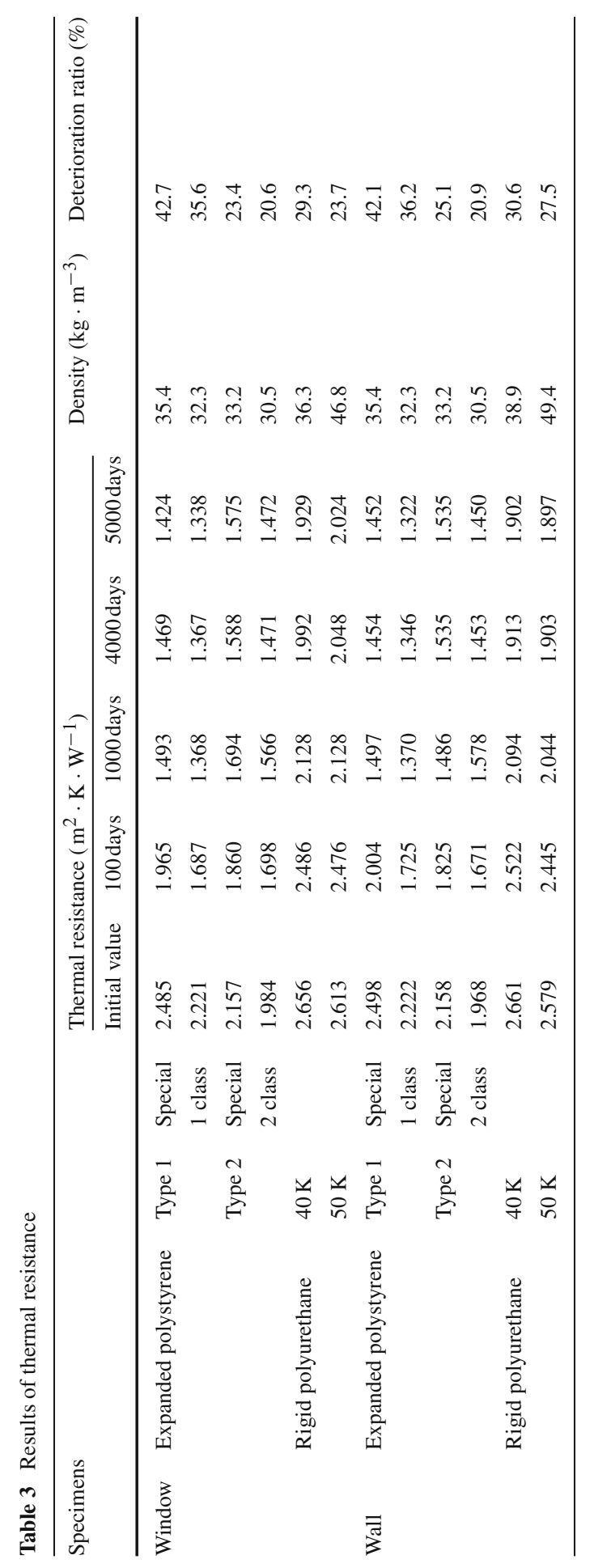


steady state regarding aging variation, and the rate of change in comparison with the initial thermal resistance after about 5000 days was $39.8 \%$ to $42.7 \%$.

(2) The initial thermal resistance of expanded polystyrene insulation material type 2 was lower than the initial thermal resistance of expanded polystyrene insulation material type 1 . The range of the rate of change after about 5000 days was $25.8 \%$ to $27.0 \%$. However, thermal resistance performance falling below KS performance standards was observed after about 80-110 days, showing the continuous aging variation.

(3) In the case of rigid polyurethane insulation material, while both specimens showed the gradual thermal drift after about 70-100 days, the rate of change increased afterward. The thermal drift below KS performance standards was shown after about 1000 days. The rate of change in comparison with the initial value after about 5000 days was $22.5 \%$ to $27.4 \%$. It seems that the aging variation was continuously in progress.

(4) The specimens installed on the glass and the wall did not show a significant difference in aging variation, indicating that environmental conditions did not influence the release of foam gas in the insulation material.

Open Access This article is distributed under the terms of the Creative Commons Attribution 4.0 International License (http://creativecommons.org/licenses/by/4.0/), which permits unrestricted use, distribution, and reproduction in any medium, provided you give appropriate credit to the original author(s) and the source, provide a link to the Creative Commons license, and indicate if changes were made.

\section{References}

1. Ministry of Land, Infrastructure and Transport, 2013, Building energy saving design standards

2. KS M ISO 11561:2009 Aging of thermal insulation materials: determination of the long-term change in thermal resistance of closed-cell plastics (accelerated laboratory test methods)

3. ASTM C518 (Standard Test Method for Steady-State Thermal Transmission Properties by Means of the Heat Flow Meter Apparatus)

4. KS M 3808:2011 Cellular polystyrene(PS) for thermal insulation

5. KS M 3809:2006 Rigid polyurethane foam for thermal insulation

6. KS L 9016:2010 Test methods for thermal transmission properties of thermal insulations 